\title{
IMPACT OF PROTECTIVE SHELTERBELT ON MICROCLIMATE CHARACTERISTICS
}

\author{
IVANA LAMPARTOVÁ ${ }^{1}$, JIŘÍ SCHNEIDER², ILJA VYSKOT², MILAN RAJNOCH³, \\ TOMÁŠ LITSCHMANN ${ }^{4}$
}

\footnotetext{
${ }^{1}$ Department of Landscape Management, Faculty of Forestry and Wood Technology, Mendel University in Brno, Zemědělská 3, 61300 Brno, Czech Republic; e-mail: ivana.lampartova@mendelu.cz

${ }^{2}$ Department of Environmentalistic and Natural Resources, Faculty of Regional Development and International Studies, Mendel University in Brno, Tř. Generála Píky 2005/7, 61300 Brno, Czech Republic; e-mails: jiri.schneider@ mendelu.cz, ilja.vyskot@mendelu.cz

${ }^{3}$ Faculty of Horticulture, Valtická 33769144 Lednice, Czech Republic; e-mail: milan.rajnoch@mendelu.cz

${ }^{4}$ AMET-association Litschmann \& Suchý, 69102 Velké Bílovice, Czech Republic; e-mail: amet@email.cz
}

\begin{abstract}
Lampartová I., Schneider J., Vyskot I., Rajnoch M., Litschmann T.: Impact of protective shelterbelt microclimate characteristics. Ekológia (Bratislava), Vol. 34, No. 2, p. 101-110, 2015.

Evaluation of microclimate characteristics of a protective shelterbelt in Obelisk enclosure in 2010. Vegetation performs indispensable functions in the landscape. Protective shelterbelts are important landscape elements. Individual interventions to these ecosystems should be made with the intention to increase the retention capacity of the landscape, the biodiversity, and the stability of individual landscape elements and the landscape as a whole. This article presents the results of the measuring of the effect of model forest vegetation in the proximity of Obelisk in the Lednice-Valtice area on the microclimate. The protective shelterbelt, declared as a forest stand, is located in the cadastral area of Lednice, Podivín and Rakvice. A set of weather stations, supplied by AMETLitschmann and Suchý Velké Bílovice, was used for the measuring. The stations measured wind velocity $(\mathrm{m} / \mathrm{s})$, soil temperature in depths of 5 and $10 \mathrm{~cm}\left({ }^{\circ} \mathrm{C}\right)$, air temperature $\left({ }^{\circ} \mathrm{C}\right)$, radiation $\left(\mathrm{W} \cdot \mathrm{m}^{-2}\right)$ and precipitation $(\mathrm{mm})$ from January 1 to December 31, 2010. The ImageTool application was used to establish optical porosity, based on photos taken in summer and winter. Optical porosity was established as a ratio of white spots to their total number in a specific section of a photograph. The optical porosity was $5 \%$ during the growing season and $23 \%$ outside the growing season. These values significantly differ from the optimum values for efficient semi-permeable PS, whose porosity is set to $40-50 \%$.
\end{abstract}

Key words: protective shelterbelts, landscape, microclimate.

\section{Introduction}

A high amount of protective shelterbelts were established in Czechoslovakia in 1950 (Pasák, 1984). They have an indispensable position in our landscape, especially in scarcely forested flatlands with dominance of light and dry soils.

Protective shelterbelts help to control erosion and blowing snow, improve animal health and survival in winter conditions, reduce energy consumption of the farmstead unit, and 
enhance habitat diversity, providing refuges for predatory birds and insects. On a larger landscape scale windbreaks provide habitat for various types of wildlife and have the potential to contribute significant benefits to the carbon balance equation, easing the economic burdens associated with climate change (Brandle et al., 2004). They protect banks of currents against erosion by their root systems; work as bio-corridors, links between landscape sections; form parts of landscapes and environments from an aesthetic point of view; affect the climate of their surroundings; inside and around, a specific microclimate is created; they prevent expansion of dust and noise; they affect the radiation, temperature and moisture of air and soil, and wind movement.

The major factors that determine the efficiency of windbreaks are height, porosity, orientation, length, and location in the landscape (Peri, Bloomberg, 2002).

Petrík et al. (1986) name these three types of protective shelterbelts-impermeable, semipermeable, and permeable. According to Holý (1978), semi-permeable windbreaks are the most suitable in average conditions. Tall semi-permeable (40-60\% porosity) shelter woods provide effective shelter to the largest area and are most appropriate for sheltering arable crops and grazing animals (Gardiner et al., 2006).

Generally, the microclimatic effect of a windbreak is obvious to a distance of the windbreak height multiplied by twenty. However, this distance is affected by the composition of windbreaks, specifically their permeability. The best performance has been observed for windbreaks of $45-50 \%$ permeability (Pasák, 1970). Dostál (2007) presents a diagram of performance of the various types of protective shelterbelts (see Fig. 1).

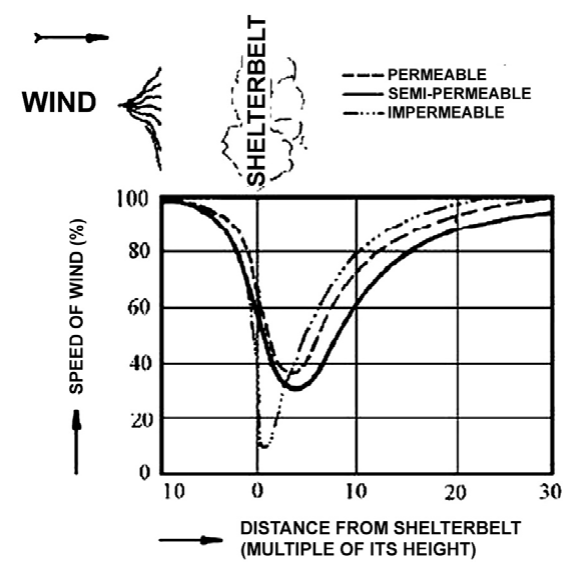

Fig. 1. Diagram of performance of the various types of protective shelterbelts (Dostál, 2007).

\section{Model area}

The model area is a forest stand, declared as a protective shelterbelt (hereinafter also PS) in the Obelisk enclosure within Lednice-Valtice area. The PS performs a function of a wind- 
break. The area is located in cadastral areas of Lednice, Podivín and Rakvice (see Fig. 2). The altitude is around $170 \mathrm{~m}$ a.s.l. Within the landscape, the stand is a part of the eastern edge of riparian stands along the Dyje River, which provides unfavourable soil conditions (water logged, clay soils, gley and semi-gley). The relief is flat. The subgrade is formed from sands and sandy gravel predominantly. The model area is climatically warm-T4 based on Quitt, characterised by very long, very warm and very dry summers; with a very short transition period; warm spring and autumn; short, mild and dry to very dry winter with a short period of snow cover.

The PS is northwest-southeast oriented. The mature stand is about $25-30 \mathrm{~m}$ tall; broadleaved young growth in the NNE part is about $3 \mathrm{~m}$. A mean width ranges around $130 \mathrm{~m}(60$ $\mathrm{m}$ in the place of measuring); a mean length is about $760 \mathrm{~m}$. The young growth in the NNE

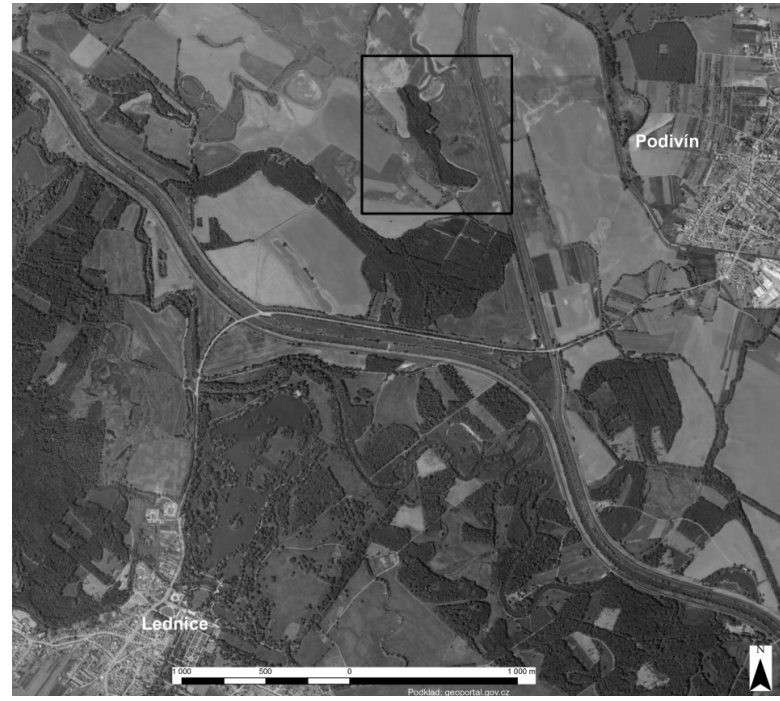

Fig. 2. Location of model protective shelterbelt.

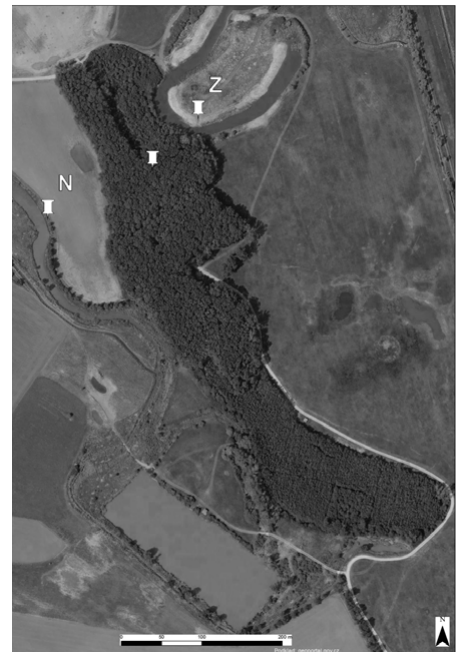

Fig. 3. Position of MeteoUNI weather station. N-windward, Z-leeward.

part of the PS was established by planting 2-3-year-old bare-rooted plants with $1 \times 0.5 \mathrm{~m}$ spacing. There are oxbow lakes on both sides of the stand. There is the adjacent Gejle to the east and Čapkovo jezero (Čapek's Lake) to the west, about $60 \mathrm{~m}$ far, with the flowing Trníček canal. There is a road network in the central part of the shelterbelt, leading in the longitudinal direction. The forest stand in the PS has two layers: the tree layer and the shrub layer. The herbal layer is missing completely from some parts, due to the closed canopy of the stand. The dominating tree species is the English oak (Quercus robur L.); there are significant representations of the field maple (Acer campestre L.), the European ash (Fraxinus excelsior L.), the small-leaved lime (Tilia cordata Mill.) and the European hornbeam (Carpinus betulus L.). The shrub layer includes e.g. the common hawthorn (Crataegus monogyna Jacq.) or the black elder (Sambucus nigra L.). The mature stand is about 80-100 years old; the young growth is about $10-15$ years old. 


\section{Material and methods}

The climatic data were recorded by means of the MeteoUNI weather station. The weather stations were placed in the south-western and north-eastern sides of the stand. Based on the fact that winds from the west predominate (Horáková, 2009) these sides are in the study referred to as 'windward' side (SW) and 'leeward' side (NE), although the measuring conducted in the monitored period indicates different results concerning the predominant wind direction. The third MeteoUNI station was located inside the forest stand (see Fig. 3). The set of weather stations measures the wind velocity $(\mathrm{m} / \mathrm{s})$, soil temperature $\left({ }^{\circ} \mathrm{C}\right)$, air temperature $\left({ }^{\circ} \mathrm{C}\right)$, global radiation $\left(\mathrm{W} \cdot \mathrm{m}^{-2}\right)$ and precipitation $(\mathrm{mm})$. The obtained data were used to ascertain the performance of the protective shelterbelt. Within the related observations, we analysed the species, spatial and age composition of the PS and the optical porosity of the stand. The optical porosity was ascertained using photos taken in summer and winter (see Figs 4a, b, and c). Litschmann and Rožnovský (2005) express the optical porosity as a ratio of white spots to their total number in a specific photo section. The ImageTool application was used for this determination. Based on the measured climatic data, the effect of the shelterbelt on the microclimate of the area was evaluated for the monitored period. Basic biotechnical measures that would contribute to reduction of microclimatic extremes within the area were proposed.

\section{Results}

The following graphs show the results of air temperature, global radiation and periods of winds in particular directions from January 1, 2010 to December 31, 2010. The comprehensive overview of the measured data has been published in Lampartová (2011).

Graphs in Figs 4a, b, c show the measured values of the mean, maximum and minimum daily air temperature. The mean temperatures on the 'windward' side and inside the windbreak were approximately the same (see Table 1). The mean temperatures in the windbreak were higher than on the 'leeward' side (see Fig. 4a). This is explained by low maximum and minimum temperatures on the 'leeward' side as compared with the windbreak centre. The maximum temperature on the 'leeward' side was lower than on the 'windward' side due to the PS shading (see Fig. 4b). The low values of the minimum temperatures indicate a possible influence of the oxbow lake on the 'leeward' side and Čapek's lake on the 'windward' side of the PS. The minimum temperatures inside the windbreak may have been higher due to the lower effect of radiation at night. The minimum temperatures on the 'windward' side were higher than on the 'leeward' side in the monitored period (see Fig. 4c).

The measured values of global radiation (see Fig. 5) show that there was much more solar radiation in the free space than inside the windbreak. The amount of radiation that penetrates tree crowns depends on the species composition of a stand and the level of closed canopy. The highest intensity of solar radiation inside the windbreak was achieved in spring, when the trees had no leaves yet. The radiation that penetrates the stand down to the ground affects the light and temperature conditions and helps to develop the herbal layer.

$\mathrm{T} \mathrm{a} \mathrm{b}$ le 1 . Daily mean air temperatures $\left({ }^{\circ} \mathrm{C}\right)$ in the monitored period.

\begin{tabular}{|l|l|l|}
\hline & The highest mean air temperature & The lowest mean air temperature \\
\hline 'windward' side & 16 July $2010=26.9^{\circ} \mathrm{C}$ & 27 January $2010=-14.8^{\circ} \mathrm{C}$ \\
\hline 'leeward' side & 14 July $2010=28.9^{\circ} \mathrm{C}$ & 27 January $2010=-17.7^{\circ} \mathrm{C}$ \\
\hline windbreak & 16 July $2010=25^{\circ} \mathrm{C}$ & 27 January $2010=-15.1^{\circ} \mathrm{C}$ \\
\hline
\end{tabular}


Graphs in Figs 6a, b and $c$ present the period for which wind blew from particular directions in the monitored period. Both the 'leeward' and the 'windward' sides were dominated by northern wind (see Figs 6a, b). The 'windward' side also had a high proportion of eastern wind (i.e. blowing from the forest stand). Inside the windbreak there was an obvious decrease of time for which any wind blew. However, the predominating winds were from south-south-western and north-western directions (see Fig. 6c). This can be explained by the effect of the forest stand on wind current, whose direction changes or turbulences arise.

Figs 7a, b (Horáková, 2009) are examples of the PS porosity in summer. The images compare the input classical photo (see Fig. 7a) and the output image in black/whitescale (see Fig. 7b). After the optical porosity of the protective shelterbelt was evaluated, it was ascertained that the porosity of the leaved and bare stand is 5 and $23 \%$, respectively.

Figures 8 and 9 compare the mean and maxi-

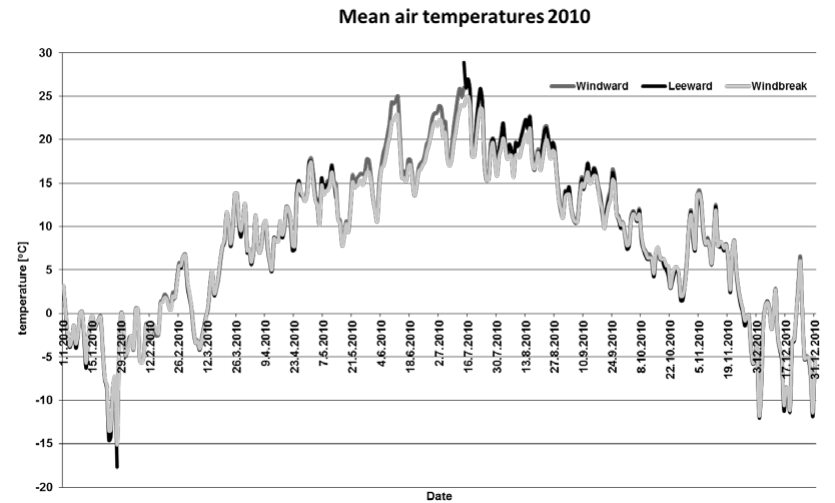

Fig. 4a. Daily mean air temperatures from January 1, 2010 to December 31, 2010.

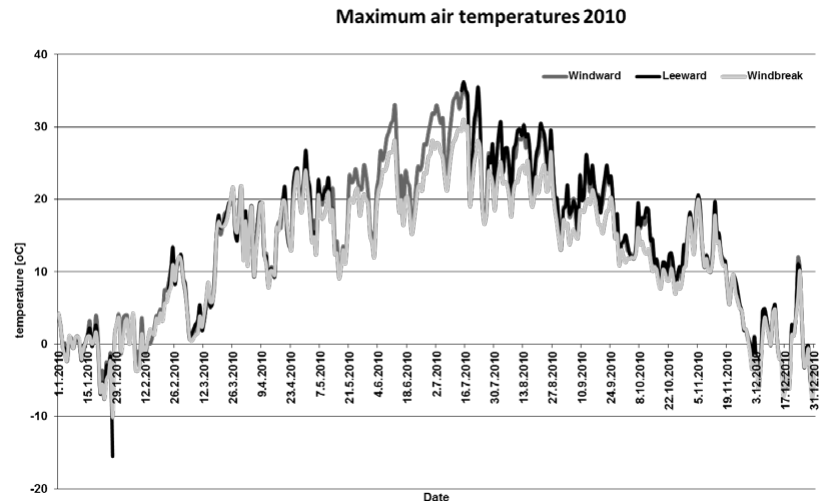

Fig. 4b. Daily maximum air temperatures from January 1, 2010 to December 31, 2010.

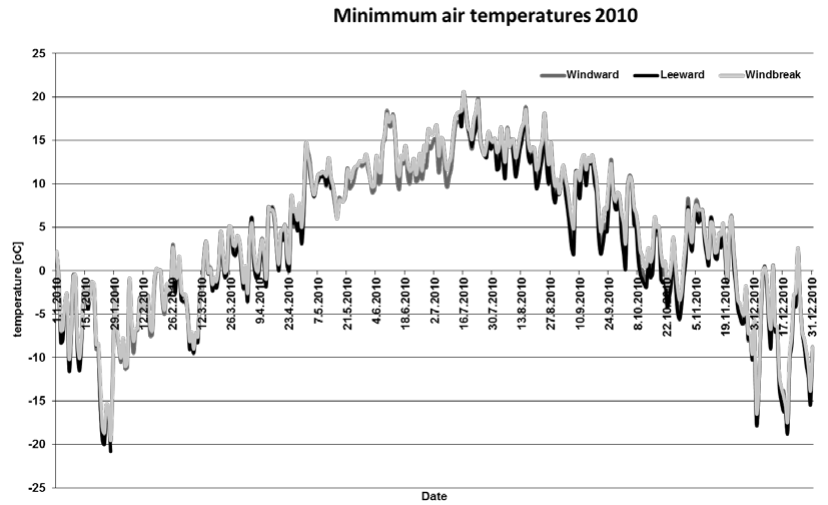

Fig. 4c. Daily minimum air temperatures from January 1, 2010 to December 31, 2010. 


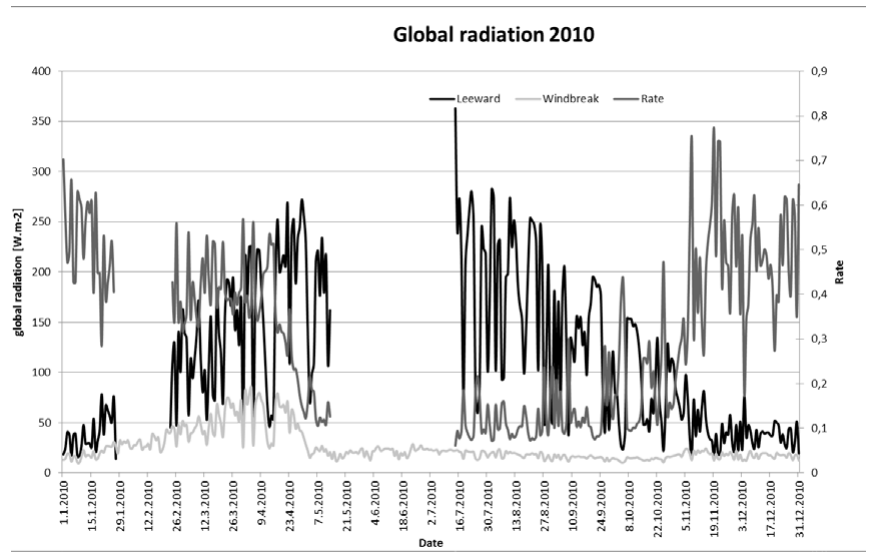

Fig. 5. Global radiation from January 1, 2010 to December 31, 2010. mum wind velocity on the 'windward' side, 'leeward' side and inside the windbreak. The low values of wind velocity in the centre of the PS indicate that the stand is too dense, impermeable. The maximum wind velocity on the 'windward' side in 2010 was measured on March 14,2010 and it was 10.6 $\mathrm{m} / \mathrm{s}$. The maximum wind velocity on the 'leeward' side was measured on the same day and it was 11.9

$\mathrm{m} / \mathrm{s}$. Figure 10 shows the differences of the maximum wind velocity on the 'windward' and 'leeward' sides. In winter, the differences range around $4 \mathrm{~m} / \mathrm{s}$.

The graphs of soil temperatures (see Figs 11 and 12) measured at depths of 5 and $10 \mathrm{~cm}$ show that the values are higher on the 'windward' side than on the 'leeward' side. The reason is the time of solar radiation, which is longer on the 'windward' side and thus heats the soil up longer. The 'leeward' side is shaded by the protective shelterbelt. The soil temperature inside the PS can be affected by snow cover in winter; the snow cover prevents radiation of heat from the soil as snow is a bad conductor of heat. Soil is thus cooled down in a slower rate.

\section{Discussion}

The location of weather sensors is supposed to testify the influence of the PS on the surrounding landscape segments. It is recommendable to add more profiles within layout of 'windward' side-stand interior-'leeward' side for a better representation character of the data.

Shelterbelt is defined as a belt of trees and shrubs that is usually more than two rows wide, and arranged as a protection for fields and crops against strong winds (Bayou, 1997). The term windbreak applies to short barriers of one or two rows of trees designed to limitation of wind flow and intended to protect buildings, soil, crops, or livestock from the effect of winds (Kenney, 1986).

A question remains to what extent the explored forest stand can be defined as a protective shelterbelt (PS). For example, Zachara (1982) defines this term as non-continuous forest stands that are divided based on the functions they perform within landscape. Středa et al. (2007) define PS as belts of trees and shrubs of various widths perpendicular to the prevailing wind direction with erosion-prevention and soil-protective functions. However, currently the timber production function predominates in the study area. The aims of forest management measures taken in the explored forest stand should be re- 
newal and maintenance of stability of the protective shelterbelt and the related multifunctionality within the landscape.

The data gained by measuring in the explored period do not correspond with the initial assumption by Horáková (2009), based on which the 'windward' (south-western) and 'leeward' (north-eastern) sides of the protective shelterbelt were determined. Considering the NW-SE orientation of the shelterbelt and the prevailing northern winds, we can say that the north-eastern side of the stand is the windward side. In spite of that, we can assume that the stand modified the direction of the wind, which was manifested inside the stand by a considerable decrease in the time of airflow and on the western side by an increase in winds blowing from the east (i. e. from the forest stand)

\section{Conclusion}

The paper presents the results of measuring climatic characteristics of a protective shelterbelt in Obelisk enclosure in 2010. The climatic data of wind velocity $(\mathrm{m} / \mathrm{s})$, soil temperature $\left({ }^{\circ} \mathrm{C}\right)$, air temperature $\left({ }^{\circ} \mathrm{C}\right)$, global radiation $\left(\mathrm{W} . \mathrm{m}^{-2}\right)$ and precipitation $(\mathrm{mm})$ were recorded by means of weather stations MeteoUNI. Photographs that were to establish optical porosity were taken in summer and winter. The results show that winds from the northern direction prevail in the examined profile. The internal environment of the stand changed it to south-south-western to north-western wind. The range of daily mean temperatures was $-17.7^{\circ} \mathrm{C}$ in January to 28.9 ${ }^{\circ} \mathrm{C}$ in July on the 'leeward' side of the stand. The optical porosity was $5 \%$ during the growing season and $23 \%$ outside the growing season. These values significantly differ from the optimum values for efficient semi-permeable
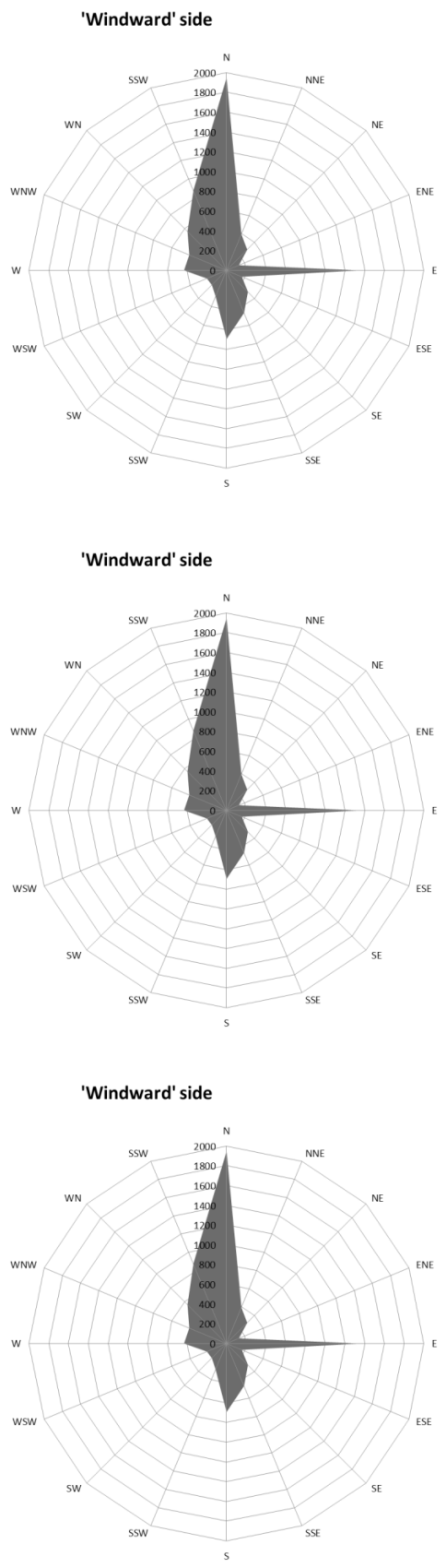

Figs $6 a, b, c$. The total time (h) for which wind blew from particular directions in the area. 


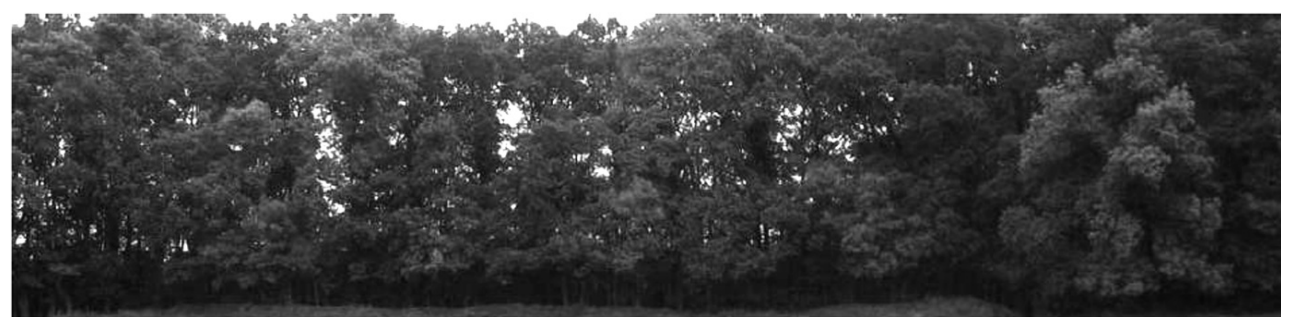

Fig. 7a. Classical photo of the PS porosity in summer (Horáková, 2009).

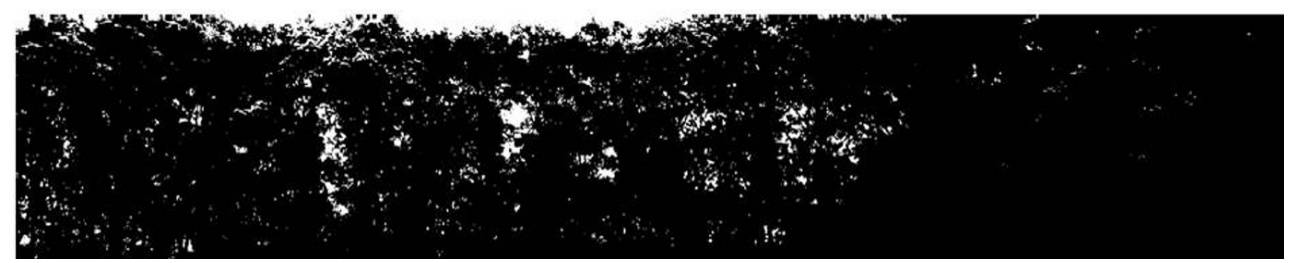

Fig. 7b. Photo of the PS porosity in summer-output image in black/white-scale (Horáková, 2009).

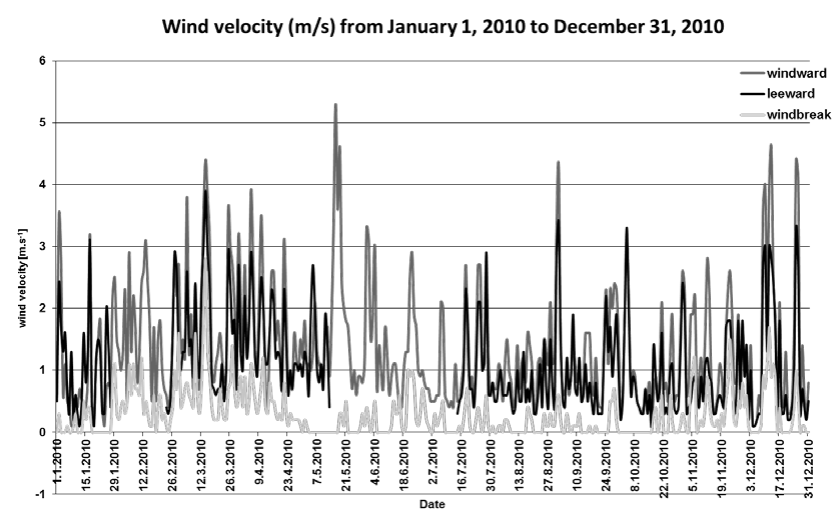

Fig. 8. Wind velocity (m/s) from January 1, 2010 to December 31, 2010.

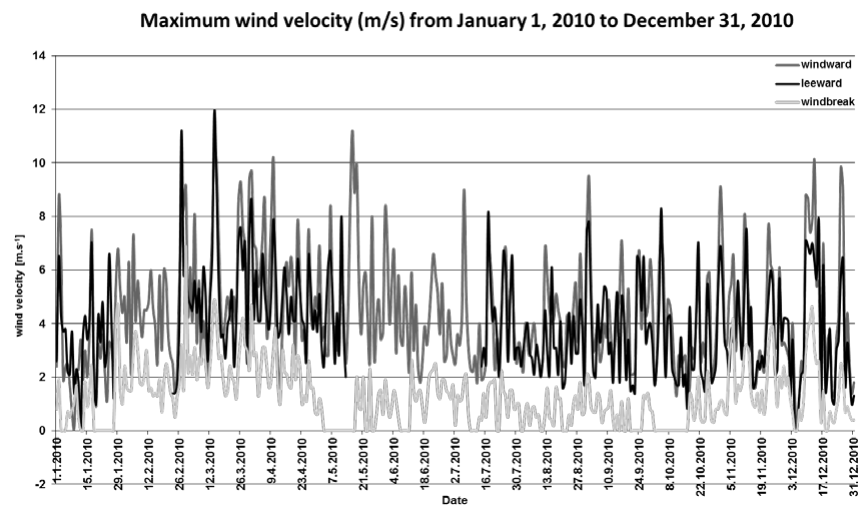

Fig. 9. Maximum wind velocity (m/s) from January 1, 2010 to December 31, 2010.
PS, whose porosity is set to $40-50 \%$. The aim of the following study should be a proposal of biotechnical measures leading to a change of this condition and improvement of functions of the protective shelterbelts.

\section{Summary}

The paper focuses on the evaluation of results of microclimatic characteristics of a protective shelterbelt in Obelisk enclosure. The Obelisk enclosure is located in the cadastral area of Lednice, Podivín and Rakvice. The aim of the study was to evaluate the effect of the protective shelterbelt on the area microclimate. Weather stations supplied by AMET- 
Litschmann and Suchý Velké Bílovice-were used to analyse the influence of the PS on the microclimate of the surrounding landscape. The weather stations were located on the 'leeward' (NE) side, the 'windward' (SW) side and in the centre of the protective shelterbelt. Data necessary to establish the functional efficiency of the shelterbelt were gained during the entire year. The set of the weather stations measured wind velocity $(\mathrm{m} / \mathrm{s})$, soil temperature $\left({ }^{\circ} \mathrm{C}\right)$, air temperature $\left({ }^{\circ} \mathrm{C}\right)$, global radiation $\left(\mathrm{W} . \mathrm{m}^{-2}\right.$ ) and precipitation $(\mathrm{mm})$. The values of optical porosity of the examined protective shelterbelt were $5 \%$ in summer and $23 \%$ in winter. The optimum windbreak permeability was $40-50 \%$. These windbreaks are referred to as semi-permeable. Based on the data gained from the weather stations and by means of optical porosity, the examined protective shelterbelt was evaluated as impermeable.

However, the current distribution of the weather stations does not allow us to evaluate the range of the effect of the protective shelterbelt on the microclimate of the surrounding landscape. The stations were located in the protective shelterbelts randomly, in unequal distances. A higher number of weather stations within the protective

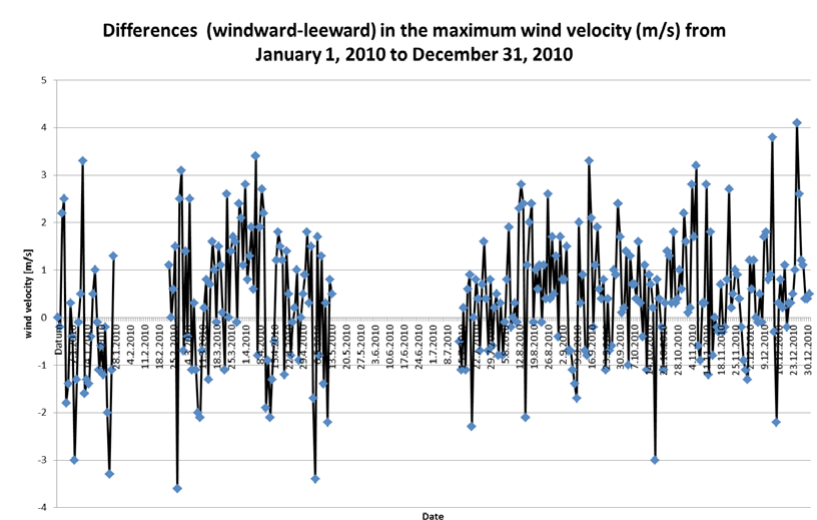

Fig. 10. Differences in the maximum wind velocity $(\mathrm{m} / \mathrm{s})$ from January 1 , 2010 to December 31, 2010.

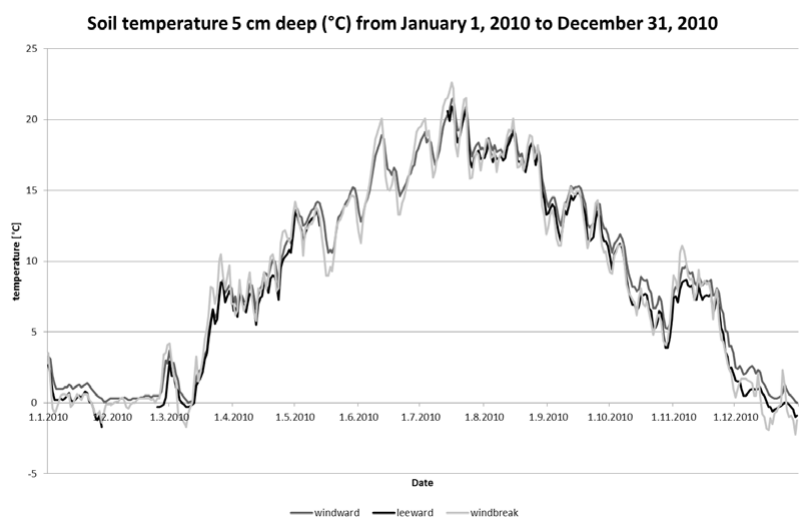

Fig. 11. Soil temperature $5 \mathrm{~cm}$ deep $\left({ }^{\circ} \mathrm{C}\right)$ from January 1,2010 to December 31, 2010.

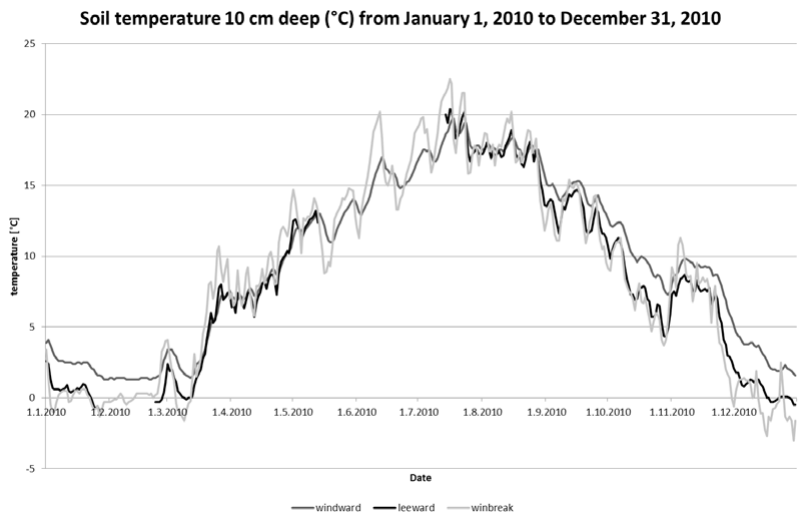

Fig. 12. Soil temperature $10 \mathrm{~cm}$ deep $\left({ }^{\circ} \mathrm{C}\right)$ from January 1,2010 to December 31, 2010. 
shelterbelt could give slightly different results. In the future, it is necessary to place a higher number of sensors in exact distances. To be able to propose further measures, it is necessary to obtain a larger set of data of long-term monitoring of the area. The current extent can only provide us with data of information character. In spite of the above mentioned facts, the acquired values correspond with other measurements (e.g. Litschmann, Rožnovský, 2005) in the Lednice-Valtice area.

It is necessary to realise that protective shelterbelts participate in the complex formation of the landscape character. They are inseparable and irreplaceable parts of the landscape.

\section{Acknowledgements}

This paper is based on results processed within research project NAZV No. 1G57004 Complex Methodology for Permanent Grass for Better Ecological Stability in Agricultural Landscape with Focus on Territories having Specific Conditions.

\section{References}

Bayou, M.M. (1997). The effect of natural fencerow on local standardized windspeed, temperature and relative humidity. $\mathrm{PhD}$ thesis, University of Toronto.

Brandle, J.R, Hodges, L. \& Zhou X.H. (2004). Windbreaks in North American agricultural systems. Agrofor. Syst., 61, 65-78. DOI: 10.1023/B:AGFO.0000028990.31801.62.

Dostál, T. (2007). Erosion protection (in Czech). http://storm.fsv.cvut.cz

Gardiner, B., Palmer, H. \& Hislop M. (2006). The principles of using woods for shelter. Forestry commision. www. forestry.gov.uk/pdf/fcin081.pdf/\$FILE/fcin081.pdf

Holý, M. (1978). Erosion protection (in Czech). Praha: STNL.

Horáková, P. (2009). Elaboration of a study of protective forest belt (in Czech). Lednice: MZLU.

Kenney, W.A. (1986). Studies on the design and management of shelterbelts and windbreaks in Southem Ontario. M.Sc., Thesis.

Lampartová, I. (2011). Evaluation of influence of revitalization measures in the agricultural landscape on the microclimate (in Czech). Lednice: MZLU.

Litschmann, T. \& Rožnovský J. (2005). Optical porosity of windbreak and its influence on the character of the flow (in Czech). In J. Rožnovský \& T. Litschmann (Eds.), Bioklimatologie současnosti a budoucnosti. Křtiny.

Pasák, V. (1970). Wind erosion on soils (in Czech). Praha: VÚM.

Pasák, V. (1984). Protection of soil against erosion (in Czech). Praha: SZN.

Peri, P.L. \& Bloomberg M. (2002). Windbreaks in southern Patagonia, Argentina: A review of research on growth models, windspeed reduction, and effects on crops. Agrofor. Syst., 56, 129-144. DOI: 10.1023/A:1021314927209.

Petrík, M., Havlíček, V. \& Uhrecký I. (1986). Lesnická bioklimatológia. Bratislava: Príroda.

Středa, T., Rožnovský, J. \& Pokladníková H. (2007). Influence of different types of forest belts on air flow (in Czech). In J. Rožnovský, T. Litschmann \& I. Vyskot (Eds.), Klima lesa. Křtiny.

Zachar, D. (1982). Forest in landscape (in Czech). Bratislava: Príroda. 